\title{
U.S. GLOBEC Northwest Atlantic/Georges Bank Program
}

\author{
Peter Wiebe, Robert Beardsley \\ Woods Hole Oceanographic Institution. Woods Hole, Massachusetts USA
}

\author{
David Mountain \\ National Marine Fisheries Service. Woods Hole, Massachusetts USA
}

Ann Bucklin

University of New Hampshire. Durham, New Hampshire USA

\section{Background}

As entertainingly documented in Mark Kurlansky's best selling book Cod: A Biography of the Fish That Changed the World, the waters off the east coast of the North American continent have long supported important fisheries. The Basques routinely fished these waters before Columbus sailed to the new world. The economic and social importance of the fish catch influenced European politics and diplomacy well before the American Revolution. Along the coast between Cape Hatteras and Newfoundland, Georges Bank is among the most productive regions for cod and other fish species.

A combination of the Bank's topography and oceanographic conditions promotes the growth of phytoplankton and zooplankton populations that are the biological foundation of the ecosystem supporting the high fish production. Interest in understanding the Bank's productivity, particularly in relation to the commercially important fish species, has fueled a robust history of interdisciplinary oceanographic observations and research in the region. Henry B. Bigelow conducted pioneering studies of the physics, plankton, and fish during the early decades of the $20^{\text {th }}$ century (Bigelow, 1926, 1927). In the 1930s, Lionel Walford studied the influence of the current patterns on the survival of the early life stages of the fish stocks (Walford, 1938). Clarke, Bumpus, and Riley made systematic vertical stratified plankton surveys of the Bank between 1939 and 1941 (Clarke et al., 1943; Riley, 1941). John Colton studied both the plankton and larval fish populations in relation to the current patterns in the 1950 s and early 1960s (Colton and Temple, 1961; Colton et al., 1968). Since the early 1960s, the National Marine Fisheries Service (NMFS) has conducted routine surveys of the fish and oceanographic conditions to support the management of the fisheries. A summary of knowledge about Georges Bank through the early 1980s was compiled in the book Georges Bank (Backus, 1987).

Georges Bank is a shoal region east of Cape Cod (Figure 1), about $300 \mathrm{~km}$ by $150 \mathrm{~km}$ in size with depths ranging from $200 \mathrm{~m}$ at the shelf break to less than $5 \mathrm{~m}$ in the central part. Geomorphologically, the Bank is an extension of the continental shelf south of New England and forms the southern boundary of the Gulf of Maine. Oceanographically, the waters on the Bank are part of a southwestward flowing coastal current system that extends from the Newfoundland shelf to Cape Hatteras. More locally, the waters in the Gulf of Maine/Georges Bank region originate from two sources (Figure 1). Relatively cold, low salinity water enters the Gulf in the surface layers from the Scotian Shelf and warmer, more saline oceanic water from over the continental slope enters at depth through the Northeast Channel. These two waters mix as they move in a general counterclockwise pattern around the Gulf of Maine to form the water that moves onto the northern side of Georges Bank. The waters on the Bank move in a clockwise direction with the major portion of the flow continuing westward from the Bank's southern flank into the Mid-Atlantic Bight. A portion of the flow recirculates to form a closed gyre around the Bank. Strong tidal mixing, particularly over the shallow, central part of the Bank, promotes high primary production. The circulation pattern transports nutrients and planktonic organisms from the Gulf of Maine onto the Bank and also removes organisms from the Bank into the slope region to the south and into the Mid-Atlantic Bight to the west.

The Bank system has experienced considerable variability on multi-year time scales, as illustrated by changes in its water temperature, salinity and plankton abundance (Figure 2). Recruitment of the Bank's fish 


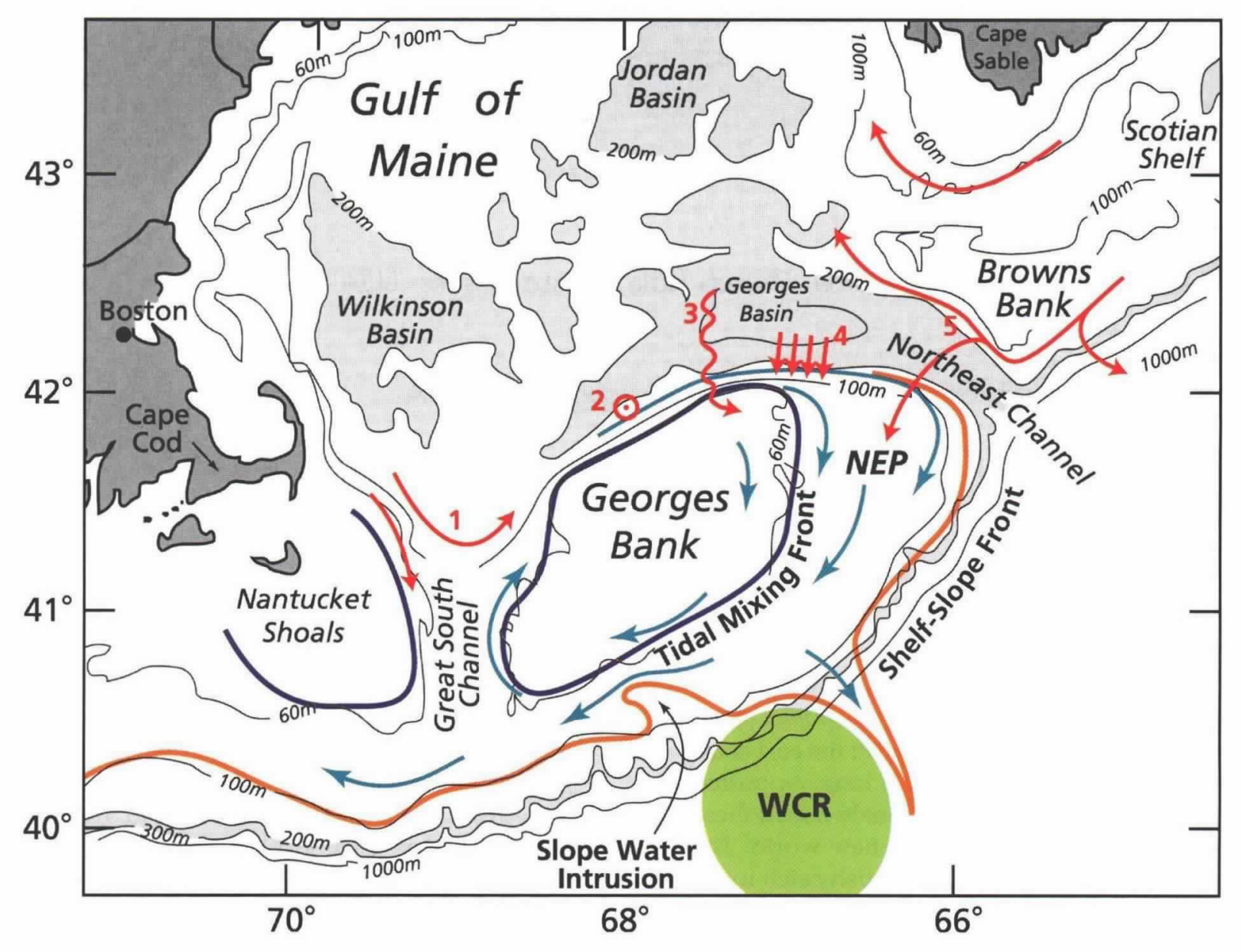

Figure 1. Schematic of Georges Bank/Gulf of Maine/adjacent shelf region, with currents shown as arrows and fronts as solid lines. "NEP" stands for Northeast Peak, "WCR" for "Warm Core Ring," and the numbers represent the following exchange processes: (1) flow across the Great South Channel and then eastward along the northern flank (the historical view), (2) up onto the Bank in a tidally driven near-bottom residual flow (Chen and Beardsley, 1998), (3) wind-driven near-surface flow onto the Bank (Lewis et al., 2001; Hannah et al., 1998), (4) small-scale cross-frontal processes (Brickman and Loder, 1993); and (5) surface intensified advection of water from the eastern side of the Northeast Channel (Scotian Shelf "Cross-over" events) (Bisagni et al., 1996).

populations also has exhibited large interannual variability not explainable by changes in the size of the adult spawning stock. Despite the wealth of observations and past research, the sources and dynamics of the physical and biological variability in the Bank's ecosystem are not well understood. No single dominant physical process appears to control the biological variability. The important physical-biological connections and trophic interactions are more subtle.

Climate analyses suggest that the Northwest Atlantic region could experience significant changes in climate over the next century, including warming by a few degrees C. Environmental variability associated with a changing climate could exert an important influence on the productivity of the Georges Bank system. The Bank lies along a zoogeographic boundary between the subarctic zone to the north and the temperate zone to the south (Herman, 1979), and represents the southern limit for many cold water species and the northern limit for many warm water species. As such, the Georges Bank ecosystem could be particularly sensitive to climate change.

In the late 1980s and early 1990s, the Georges Bank region gained national attention due to the collapse of the traditional groundfish stocks and the economic burden the collapse put upon the local fishing communities. Beginning in 1994, stringent management measures were imposed that greatly reduced harvesting of the depleted groundfish stocks, and those stocks have begun to recover. To effectively manage the harvesting of the fisheries in the long-term will require understanding how environmentally-driven ecosystem vari- 

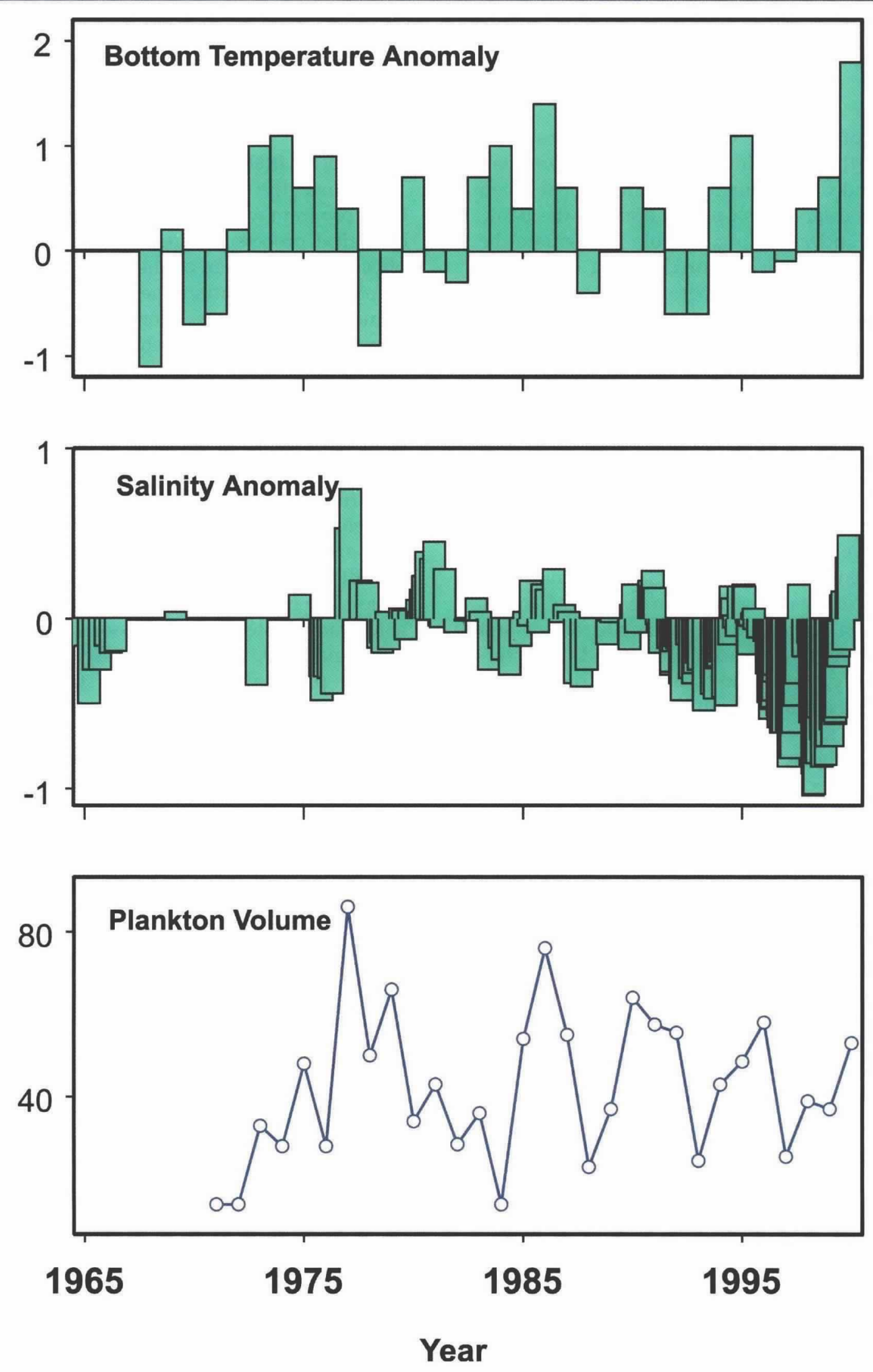

Figure 2. Bottom temperature anomaly for Georges Bank from the NMFS spring trawl survey (top panel). Salinity anomaly for Georges Bank water (adapted from Mountain, in press) (middle). Plankton displacement volume on Georges Bank in spring (Mountain et al., 2000) (bottom). 
ability influences the reproductive success of the stocks through changes in the growth and survival of the early life stages of the fish.

\section{Introduction}

The goal of the U.S. GLOBal ocean Ecosystem (GLOBEC) Northwest Atlantic/Georges Bank program is to understand the population dynamics of selected zooplankton and larval fish populations on the Bank, and with that understanding, be able to evaluate the potential effects of a varying or changing climate on the Bank's ecosystem. The program was designed to address this objective by investigating the underlying physical and biological processes that control the population dynamics of four target species: the egg and larval stages of two groundfish species, Atlantic cod (Gadus morhua) and haddock (Melanogrammus aeglefinus), and the zooplankton Calanus finmarchicus and Psuedoclanus that are prey for the larval fish (GLOBEC, 1992). These species were chosen because they are important members of the Georges Bank and other North Atlantic ecosystems, and their populations are thought to be sensitive to changing climatic conditions, a growing concern for fisheries management. Georges Bank was chosen as the primary study site for this first U.S. GLOBEC program because its size and characteristic circulation pattern would allow the developing populations to be tracked while studied; it is in a region expected to be affected by significant climate variability; and the wealth of previous work would provide an informed foundation for the new studies.

The peak spawning for cod and haddock occurs in the late winter-early spring (February-April) over the northern and eastern parts of George Bank. The eggs and larvae develop to be active swimming demersal juveniles by summer (June-August). Environmental variability is most likely to affect the survival and ultimate recruitment of the fish during the planktonic, pelagic period between spawning and demersal settlement. During this period the fish are carried clockwise around to the southern flank of the Bank from where, depending upon the flow field at the time, they may be removed from the Bank into the Slope Water to the south (e.g. by episodic wind events or warm-core rings), transported westward into the Mid-Atlantic Bight or moved northward by the gyre-like circulation to be retained on the Bank. During this same period the target zooplankton species characteristically exhibit increased production and abundance on the Bank. The environmental conditions experienced by these organisms change through the period with the beginning of seasonal warming in March and the onset of stratification on deeper $(>60 \mathrm{~m}$ ) parts of the Bank by mid-April. The vital rates of each of the target species are strongly dependent on water temperature (Laurence and Rogers, 1976; Corkett and McLaren, 1978; Campbell et al., 2001); their trophic interaction can be influenced by the degree of stratification in the water column
(Buckley and Lough, 1987); and their location on the Bank can be determined by a variety of physical processes that control the movement of water onto, around and off of the Bank (Davis, 1984; Lough, 1984; Polacheck et al., 1992).

\section{Program Description}

To meet the objective identified above, the Georges Bank program was designed to investigate the relevant biological processes in relation to three aspects of the physical environment on the Bank-the seasonal development of stratification, the circulation of water which influences the sources, retention and loss of organisms from the Bank, and the exchange of water and particles across the frontal features around the Bank. These physical phenomena were chosen because each has been shown to influence the target organisms and each is likely to be affected by climate change. To undertake these investigations the Georges Bank program was constructed with four major programmatic elements: modeling, retrospective analyses, broad-scale studies and process-oriented studies, following the overall GLOBEC research approach (Fogarty and Powell, this issue). The field program was structured to have alternate years of intensive process-oriented studies in 1995, 1997, and 1999, with each focused around one of the chosen physical phenomena (stratification, sourceretention-loss, and frontal exchange, respectively). The broad-scale studies (via ship, drifters, moorings and satellites) were conducted each year (1995-1999) and provided a broader spatial and temporal context within which the finer-scale process studies can be interpreted. The field effort focused on the January-July period each year, which covered the early planktonic stages of cod and haddock. The field work was completed in late 1999, and subsequent work has focused on data analysis, modeling and synthesis. Over 70 scientific investigators from 25 institutions in the U.S. and Canada have collaborated in this program. Brief descriptions of the four major elements follow.

\section{Modeling}

Modeling has been an essential part of the effort to interpret and synthesize the field and experimental measurements. The initial physical and subsequent combined physical and biological models were designed to capture the collective understanding of the processes that control the distribution and abundances of the target species. Physical models were developed for both idealized process studies and the regional Georges Bank/Gulf of Maine circulation featuring realistic bathymetry and bimonthly climatological forcing and stratification. The output from these models was then used to drive both individual-based and NPZtype biological models to investigate the population dynamics and to hind-cast distributional property fields in an effort to find the links between the observed spatial changes in the target species concentrations and 
the physical and biological processes responsible for the changes. This effort has been made possible by the development of a significant archive of data concerning abundance and distribution of the target species, source regions, and vital rates. During the 1999 field effort, real-time assimilative models were developed and run at sea to help integrate data collected during the cruise and guide sampling.

\section{Retrospective/Synthesis Analyses}

Retrospective studies have focused on both the hydrography and biology of Georges Bank. The occurrence of advection of Scotian Shelf water across the Northeast Channel from Browns to Georges Bank was investigated using historical hydrographic data, and a climatology of water properties developed for comparison with program measurements and modeling. Analysis of existing zooplankton data sets, such as the MARMAP zooplankton data covering the period 1977-1987 and the Clark-Bumpus-Riley surveys conducted in 1939-1941, was done to help to identify trends in zooplankton composition on Georges Bank and in adjacent regions.

\section{Broad-scale Studies}

The broad-scale studies included multi-disciplinary moorings, long-term drifter deployments, analysis of satellite data, and shipboard surveys. The broadscale survey cruises were conducted monthly from January through June (February-July in 1995). These cruises carried out CTD (Conductivity, Temperature and Depth), zooplankton, larval fish, and acoustic surveys of Georges Bank and adjacent waters (Figure 3a). On each survey cruise approximately 80 stations were occupied, with 41 of these (termed Standard Stations) located to provide a uniform, bank wide coverage. At all standard stations, a Bongo tow, a CTD cast and a 1$\mathrm{m}^{2}$ MOCNESS (Multiple Opening/Closing Net Environmental Sensing System) tow were done. At approximately 18 of the standard stations, a plankton pump and $10-\mathrm{m}^{2}$ MOCNESS were also deployed. The rest of the stations were located mid-way between the Standard Stations. At these stations, a Bongo net tow was done to provide more intensive coverage of the larval cod and haddock during the first five months of the year. On the June survey the mid-way Bongo tows were not done and a $10-\mathrm{m}^{2}$ MOCNESS tow was conducted at all Standard Stations, instead. The collection and analysis of the broad-scale data included hydrography, nutrients and chlorophyll, zooplankton biomass and species identification, fish larvae assessments including aging by otolith analysis, invertebrate predator assessments, and high frequency acoustic backscattering.

\section{Process Studies}

The first intensive process-oriented study was conducted during the winter, spring, and summer of 1995. Designated the Stratification Study, the Phase I field effort included a coordinated set of physical and biological measurements designed to test the central hypothesis that the spring development of vertical stratification and reduced wind-driven mixing over the southern flank of Georges Bank strongly influence the distribution of the zooplankton food supply, thus influencing the vital rates and survival of cod and haddock during their planktonic early life stages (Figure 3b). Physical measurements included moorings to measure the surface forcing and ocean response and microstructure studies to quantify turbulent mixing and its effects on stratification on the southern flank. Vital rates studies were carried out on cohorts of the target species. Studies of the impact of predators on the target species were carried out. The small-scale spatial distribution of these species was studied using the newly developed Video Plankton Recorder.

The 1997 Phase II process study focused on the sources, retention, and losses of water and organisms from over and around Georges Bank (Figure 3b). Tests of hypotheses concerning retention and loss of the target species involved four main activities: (1) quantification of target species abundance patterns across Georges Bank and through their growth season; (2) measurement of the vital rates of target species; (3) quantification of physical exchanges of water and biota across the boundaries of the Bank; and (4) determination of the interaction of vertical migration and vertical position maintenance behavior on retention and loss of planktonic animals on the Bank. Investigations included studying plankton and water exchanges on/off the Bank using MOCNESS and a high resolution multispectral fluorometer, SeaSoar, and VPR, and studies of the overwintering stock of Calanlus and its predators in the basins of the Gulf of Maine during the fall.

The primary focus for the 1999 Phase III field study was on cross-frontal exchange processes (Figure $3 b$ ). The Georges Bank region has major frontal features around the periphery of the Bank (fronts between slope and bank waters along the southern flank of the Bank and between bank and Gulf of Maine waters along the northern edge of the Bank) and a tidal mixing front located near the $60-\mathrm{m}$ isobath which surrounds the well-mixed water over the shallow crest of the Bank (Figure 1). The exchange of physical and biological properties across these fronts influences the supply of nutrients for primary production, the retention (loss) of the target species and their prey on (from) the Bank, and interactions between the target species, their prey and their predators. Cross-frontal exchange is influenced by physical processes which determine the location, deformation and movement of the front, including tides, winds, seasonal heating/cooling and offshore forcing, and by biological characteristics and behavior which may enhance or minimize exchange. Frontal regions often are regions of aggregation for marine plankton, because of physical processes such as divergence or convergence and because of the biological 


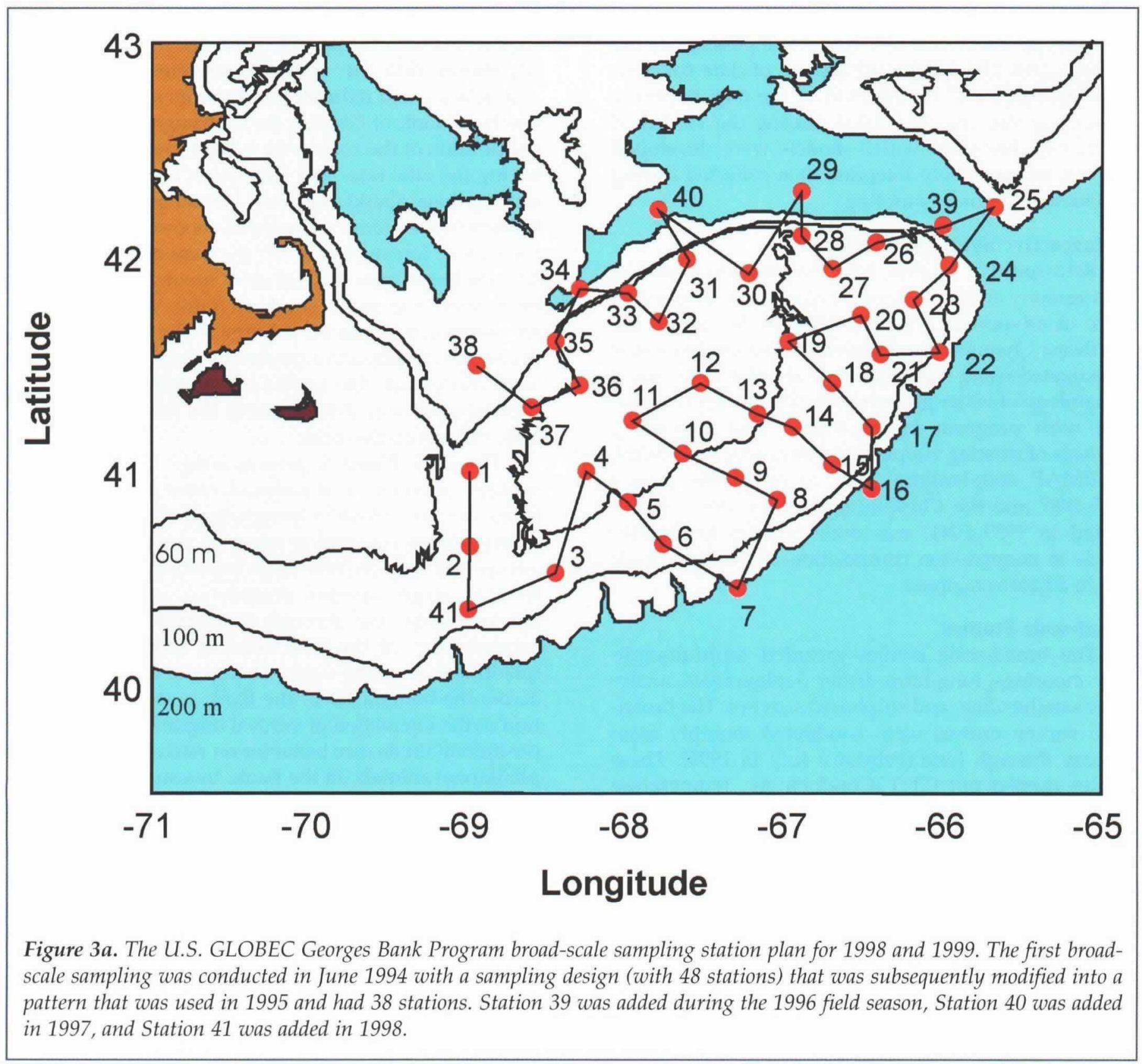

response such as enhanced production or behavior (i.e. depth-keeping swimming). Such aggregations of plankton naturally provide an enhanced food source for predators including larval cod and haddock.

The 1999 field work was designed to investigate the fine-scale patterns of the physical and biological fields comprising fronts. In particular, work was focused on: (1) the three-dimensional circulation associated with the fronts around and on Georges Bank; (2) determination of the patchiness structure of plankton and larval fish observed at the frontal structures on the Bank; (3) determination of exchange rates, due to frontal processes, of water properties and the target species across the fronts on the Bank; (4) the biological and physical processes that interact to control cross- frontal exchange of target organisms; (5) how frontal movements influence the exchange of water and organisms across the different fronts; and (6) how the crossfrontal exchange rates of water and target species vary on seasonal time scales. Within the context of the crossfrontal exchange emphasis, there were continued cohort studies to determine the vital rates of the target species and the influence of frontal processes upon these rates.

Although each phase has a different primary focus, information on all processes, e.g., stratification, retention and loss, and frontal processes, was collected during all intensive process-study years. 


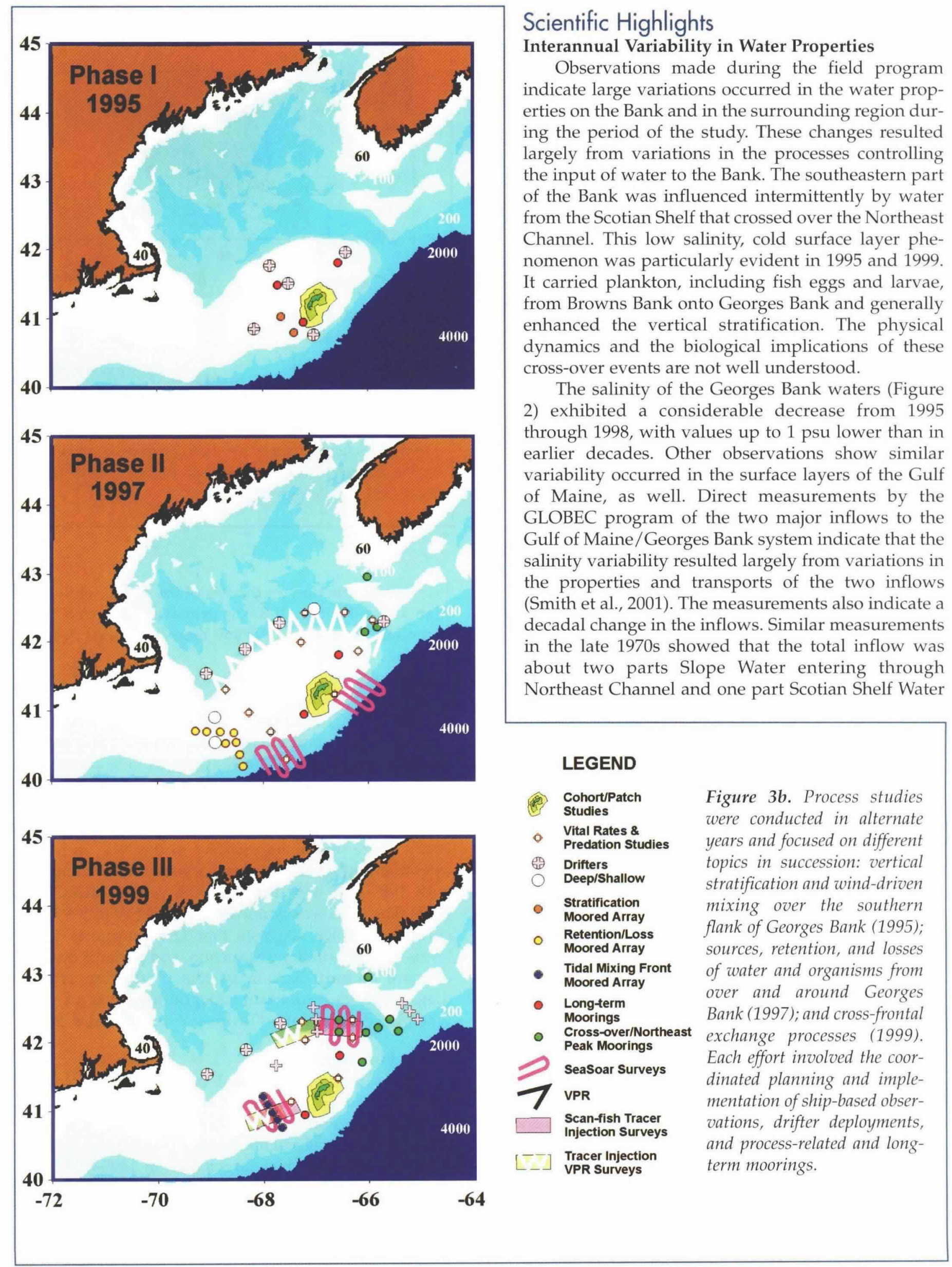


entering around Cape Sable. The GLOBEC measurements indicated about the same total transport, but with two parts Scotian Shelf water to one part Slope Water. This reversal of the proportions of the two inflows caused the general decrease in salinity during the 1990s, and likely also provided different levels of nutrients and plankton populations to the Gulf of Maine/Georges Bank region.

During 1998, the Slope Water entering the region through the Northeast Channel became colder and fresher, indicating a Labrador Sea influence. The westward extension of Labrador Slope Water (LSW) during 1997 along the Scotian Shelf was documented by Drinkwater et al. (2002) and was believed a response to the sharp drop in the North Atlantic Oscillaton (NAO) during the winter of 1996. During 1998, LSW spread through the basins of the Gulf of Maine and contributed to the waters entering onto Georges Bank. Labrador Slope Water had not been observed within the Gulf of Maine since the mid-1960s, the last time the NAO exhibited comparably low values. The mechanistic connection between the NAO and the westward extension of Labrador Slope Water is not well established. However, it represents a regional scale oceanic response to large scale atmospheric forcing that alters the waters entering onto Georges Bank. The biological implications for Georges Bank of the LSW event are not yet clear, although the LSW generally has lower nutrient levels and lower Calanus abundance than the warmer Slope Water it displaced.

\section{Nutrient Dynamics}

Georges Bank is biologically productive because: (1) it is shallow enough that light-limitation of phytoplankton is usually not important; (2) it is surrounded by deep waters rich in inorganic nutrients, which are in close proximity to, and readily available for mixing with Bank waters; (3) vigorous tidal mixing promotes the injection of these deep inorganic nutrients onto the Bank where subsequent dispersion and advection of those fluxes drive the Bank's biological oceanography (Townsend and Pettigrew, 1997; Chen and Beardsley, 1998; Townsend and Thomas, 2001, 2002) (Figure 4). Following the winter-spring phytoplankton bloom, a donut-like band of elevated "new" phytoplankton production typically forms in response to cross-isobath fluxes of nutrients (Dugdale and Goering, 1967; Eppley and Peterson, 1979) and is available for transfer to higher trophic level biomass (zooplankton and fish). Nutrient fluxes are greatest on the northern edge of the Bank where bathymetry is steepest (Pastuszak et al., 1982; Townsend and Pettigrew, 1997; Chen and Beardsley, 1998; Franks and Chen, 2001; Houghton and Ho, 2001), and those phytoplankton and newly injected nutrients circulate clockwise to the southern flank, fueling higher trophic level production along the way leading to increased zooplankton biomass, which on average, is highest on the southern flank (Davis, 1984).

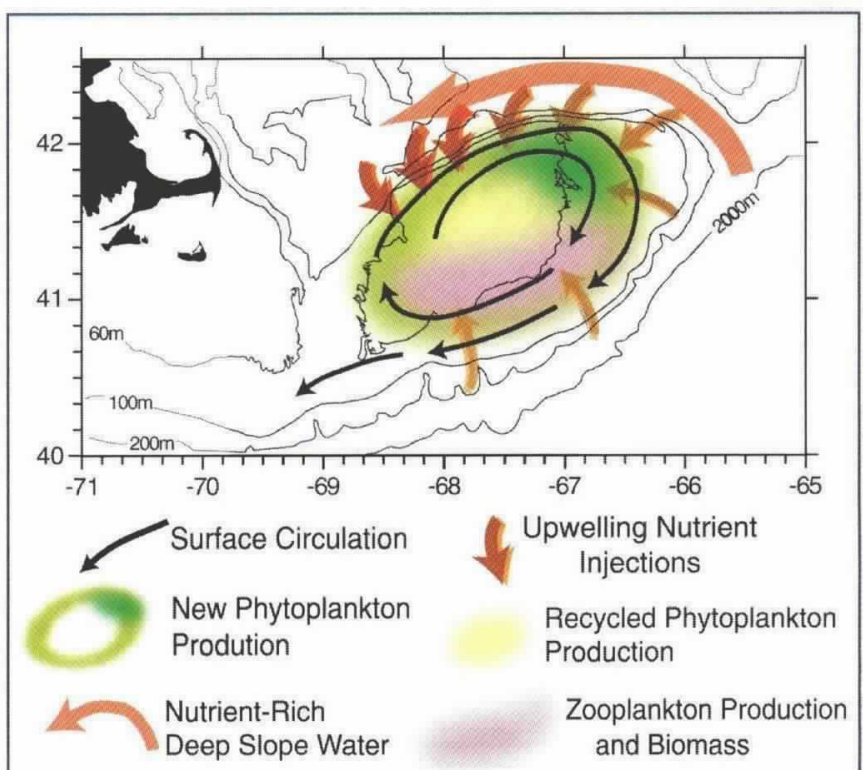

Figure 4. Schematic representation of processes important to the biological oceanography of Georges Bank (after Townsend and Pettigrew, 1997).

Primary production on the top of the Bank, while very high (O'Reilly et al., 1987), is primarily "recycled," and secondary production of new biomass is thus N-limited there.

A major source of nutrients to Georges Bank and the Gulf of Maine-Slope Water via the Northeast Channel (NEC; Townsend, 1998) — varies among years both in absolute concentrations of nutrients and in their ratios to one another. The NAO appears to control the relative importance of cold and fresh Labrador Slope Water (LSW) versus Warm Slope Water (WSW) that comprises the deep NEC influx (Drinkwater et al., 2002). There was a slug of LSW in the NEC in March 1998 that had lower nutrient concentrations compared with 1999 and had different N:Si ratios (MERCINA, 2001). The NEC was dominated with WSW in 1999. The current evidence suggests that LSW supports lower levels of new primary production, and perhaps because of more uniform N:Si ratios less production of nondiatom species (important copepod food) versus years when WSW dominates (Townsend and Thomas, 2002).

\section{Larval Fish Dynamics}

The sampling conducted on the broad-scale surveys showed large differences between years in the abundance of both cod and haddock larvae (Figure 5). For both species larval abundance was highest in 1998, being three to ten times larger than in 1995-1997. The high larval numbers did not result simply from a larger number of eggs, as egg production in 1998 was lower than in most of the other years. The variations in larval 


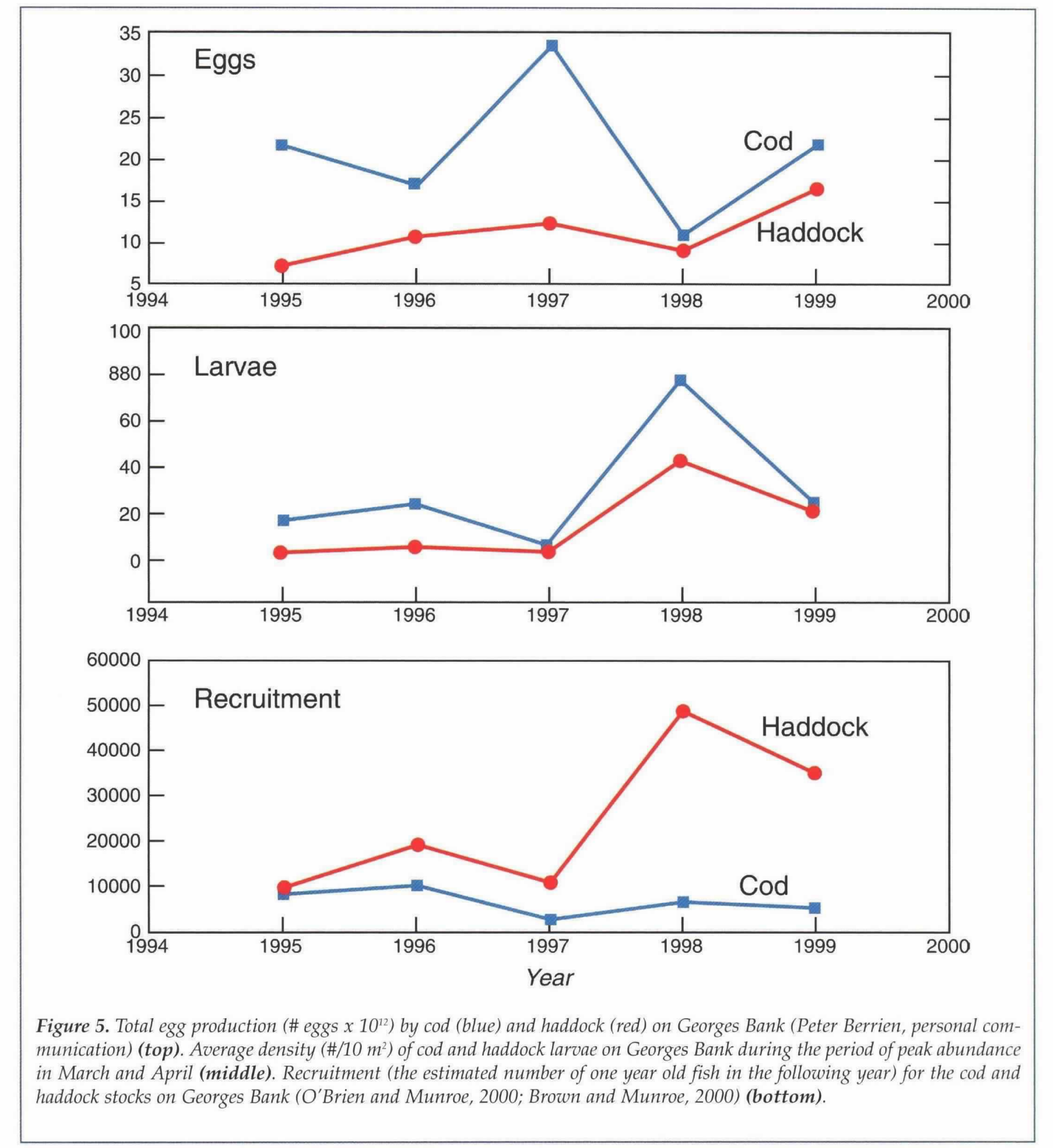

abundance for haddock, however, were similar to the variations in subsequent recruitment, with 1998 haddock year class being the largest in over 20 years. The implication is that variation in recruitment of haddock was determined largely through differences in mortality during the egg and early larval period. For cod, the variations in larval abundance and subsequent recruitment were not similar, and in particular, the high larval abundance in 1998 did not result in a higher level of recruitment.

The growth rates of individual cod and haddock larvae on Georges Bank were measured using an RNA/DNA method as a part of the process studies in 1995, 1997, and 1999. The results were expressed as a function of the water temperature and compared to laboratory studies, which were conducted with abundant 
food being available to the larvae (Figure 6). At the low end of the temperature range (near $4^{\circ} \mathrm{C}$ ), the fieldcaught larvae were growing at nearly the same rate as the laboratory fish. At progressively higher temperatures, the growth rates of the field-caught larvae fall progressively further below the laboratory curve. The increasing difference between the field and the laboratory results suggests that with increasing temperature, the larvae on Georges Bank are becoming more and more food limited as their increasing metabolic requirements are not able to be met by the available food.

\section{Zooplankton Population Dynamics and Rate Processes}

During the first three phases of the Georges Bank/Northwest Atlantic program, intensive observations of seasonal and spatial patterns of target zooplankton abundance and rates of reproduction, growth and mortality were made during the broad-scale and process cruises. Here we highlight three new insights into the dynamics of zooplankton populations on the Bank.

\section{- Interannual Variation in Reproduction of \\ Calanus finmarchicus}

The reproduction of Calanus finmarchicus, the biomass-dominant planktonic copepod during spring on Georges Bank, was measured between January and June during each year of the broad-scale surveys. The Reproductive Index, derived from evaluation of maturation state in preserved females collected at each station, estimates the daily number of eggs produced by each female. The Egg Production Rate combines this female-specific egg laying rate with the abundance of females measured at each station, yielding the number

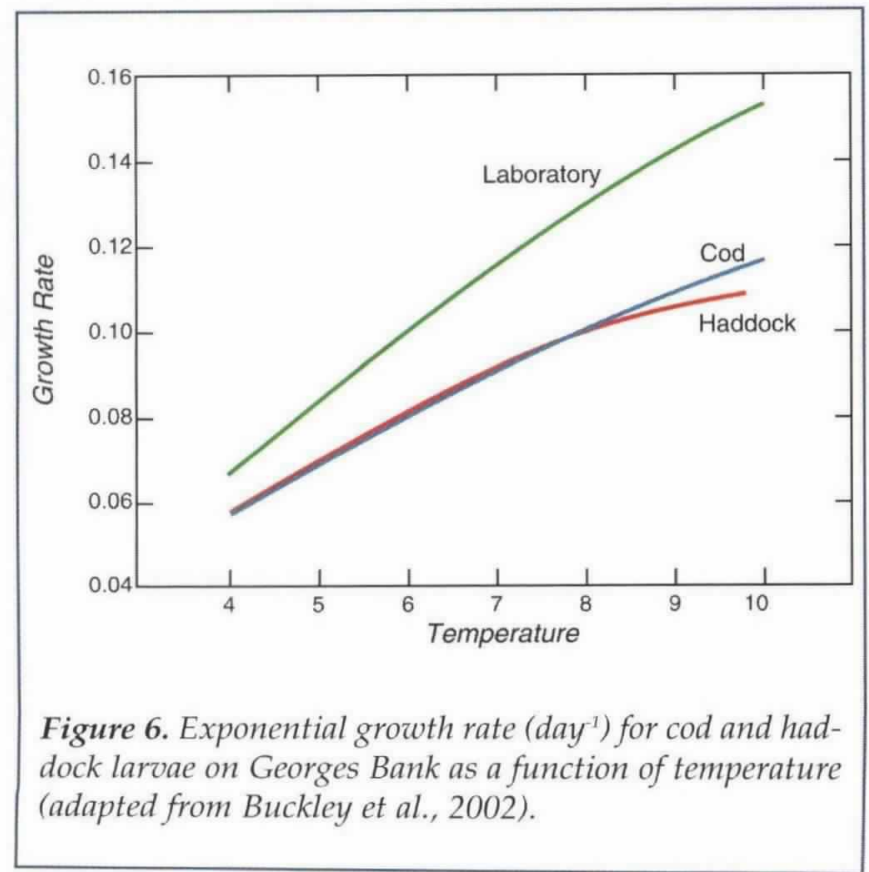

of eggs produced per $\mathrm{m}^{2}$ each day. The results from survey cruises in April of 1995 and 1998 (Figure 7) show substantial differences in the magnitude and spatial pattern of egg production between years. In 1995, for example, egg production rates were low on the eastern part of the Bank, due to a combination of low abundance of females on the northeast peak and low femalespecific egg laying rates on the southern flank. In contrast, in April, 1998, egg production rates were 5-10 times higher in the same areas of the Bank, a result of increases in both female abundance and egg laying rate. These spatial and interannual variations may have significant consequences for the growth and survival rates of early life stages of cod and haddock that are known to hatch and feed in these areas in spring (Runge et al., 2000).

\section{- Food Limitation of Growth and Reproduction of Calanus in Spring}

Phytoplankton production on Georges Bank is high and relatively constant through the year. Calanus finmarchicus has been observed to grow and reproduce on the Bank even in January (Durbin et al., 1997). However, process cruises conducted during the first phases of the program have demonstrated that significant food limitation of Calanus growth and reproduction can occur on the southern flank during April-May of certain years (Figure 8; see also the Reproductive Index in 1995 on the western half of the southern flank in Figure 7). Food limitation on the southern flank in April is a recurrent but variable feature, arising from a combination of changes to stratification and increased grazing pressure by copepods.

\section{- Stage Specific Patterns of Calanus and Pseudocalanus Mortality}

The extensive observations (over 2,500) of stage abundance and egg production rates at broad-scale survey stations over all months and years of the program have provided data for the first ever comparative study of stage-specific patterns of mortality in the target zooplankton species (Ohman et al., 2002). The mortality rates were determined by the vertical life table approach, which estimates the joint mortality rates for each successive pair of developmental stages.

Calanus and Pseudocalanus exhibit markedly different patterns of mortality on Georges Bank (Figure 9). For C. finmarchicus, which releases its eggs directly into the water, the highest mortality rates occur in the egg and earliest naupliar stages, with a second, smaller mode of higher mortality in the late naupliar and first copepodite stages (Figure 9). The mortality rates of the early stages of Calanus are positively related to population density at high female abundances, probably due to egg cannibalism. For Pseudocalanus species, whose females carry their eggs until hatching, the mortality rates are relatively uniform. The results show that, while the average egg production rate of Calanus finmarchicus is over 19 times that of Pseudocalanus, there is 


\section{Reproductive Index}
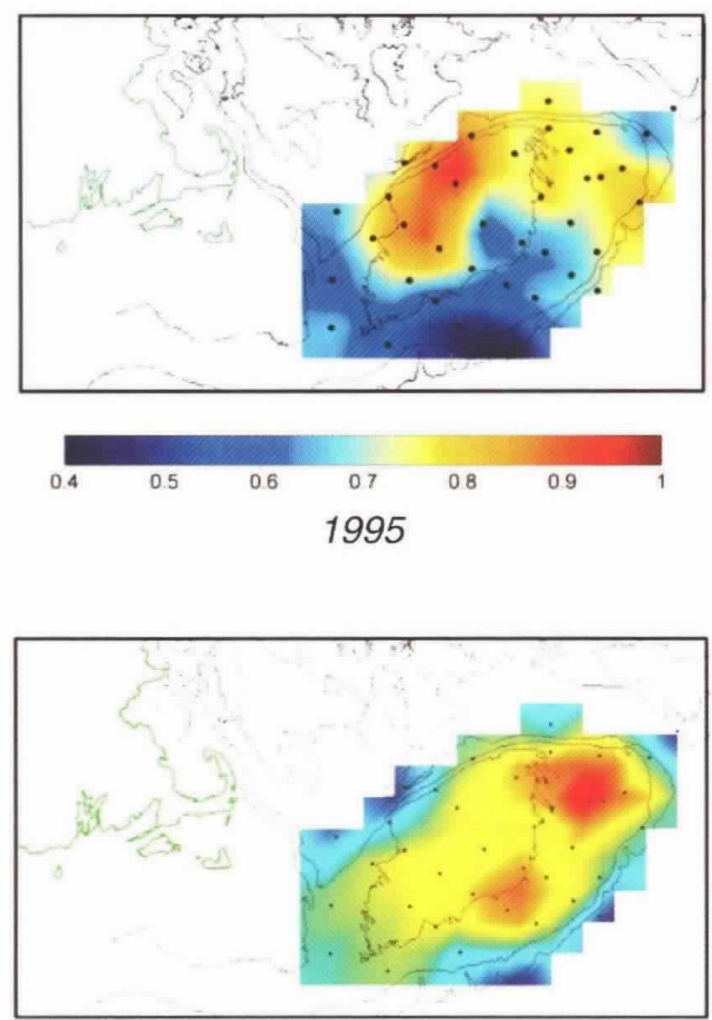

$\begin{array}{lllllll}0.3 & 0.4 & 0.5 & 0.6 & 0.7 & 0.8 & 0.9\end{array}$

1998

\section{Egg Production Rate}
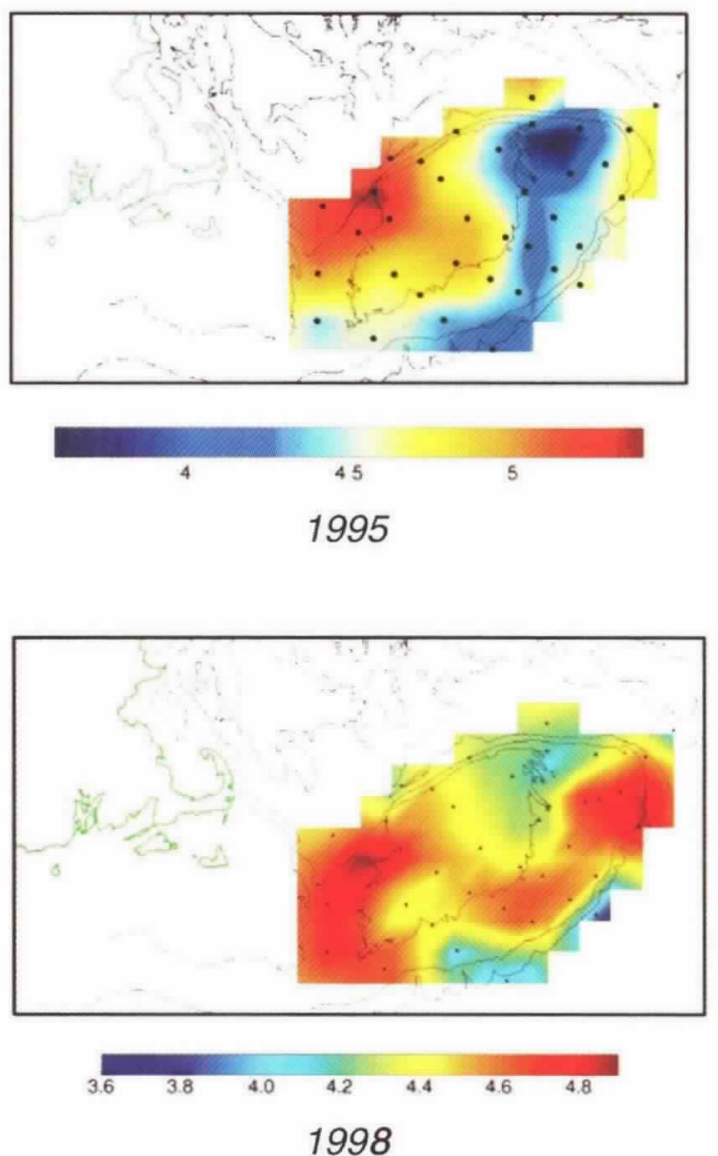

Figure 7. Estimates of the Reproductive Index (proportion of females with mature oocytes), an estimate of daily egg laying rate per female and the Egg Production Rate (log scale: $\operatorname{eggs}_{\mathrm{g}} \mathrm{female}^{-1} \mathrm{~d}^{-1}$ ) of the planktonic copepod, Calanus finmarchicus, during broad-scale survey cruises in April of 1995 and 1998 (adapted from Runge et al., 2000).

a compensating difference in mortality, such that the fitness of the two contrasting life histories appears to be approximately equal on Georges Bank.

\section{Individual-Based Trophodynamic Modeling of Larval Cod and Haddock}

Individual based models (IBMs) permit examination of the properties of ecological systems by considering the properties of individuals constituting them. Individual differences can arise from variation in physiological and/or behavioral traits. These differences, coupled with interactions among individuals, collectively give rise to growth and size distributions that provide a measure of the state of the population. Models of early life histories of larval cod and haddock on Georges Bank have coupled advanced ocean circulation models (Naimie, 1996) and field data to include the effects of realistic temporal and spatial variation of currents, turbulence, light, prey, etc., on behaviorally modified dispersal trajectories and growth. Explicit consideration of spatial heterogeneity is critical to understanding recruitment process through the determination of retention and loss mechanisms, as well as food limitation (see Werner et al., 1993, 1996, 2001; Page et al., 1999).

These models are based on standard bioenergetic supply-demand functions, in which growth is represented as the difference between the amount of food assimilated by a larva and the metabolic costs of its daily activities. The amount of food ingested is a function of the number of prey encountered, captured and eaten, while the metabolic costs are a function of larval size, ambient temperature, swimming speed, etc. In the model, prey biomass ingested by the larvae is a combination of the prey types available to the larvae including naupliar and copepodite stages of the target zooplankton species and other selected zooplankton species. Encounters between larvae and their prey are enhanced by local turbulence as modified by the swimming behavior of the fish larvae. Post-encounter inges- 


\section{Calanus Stage C4}

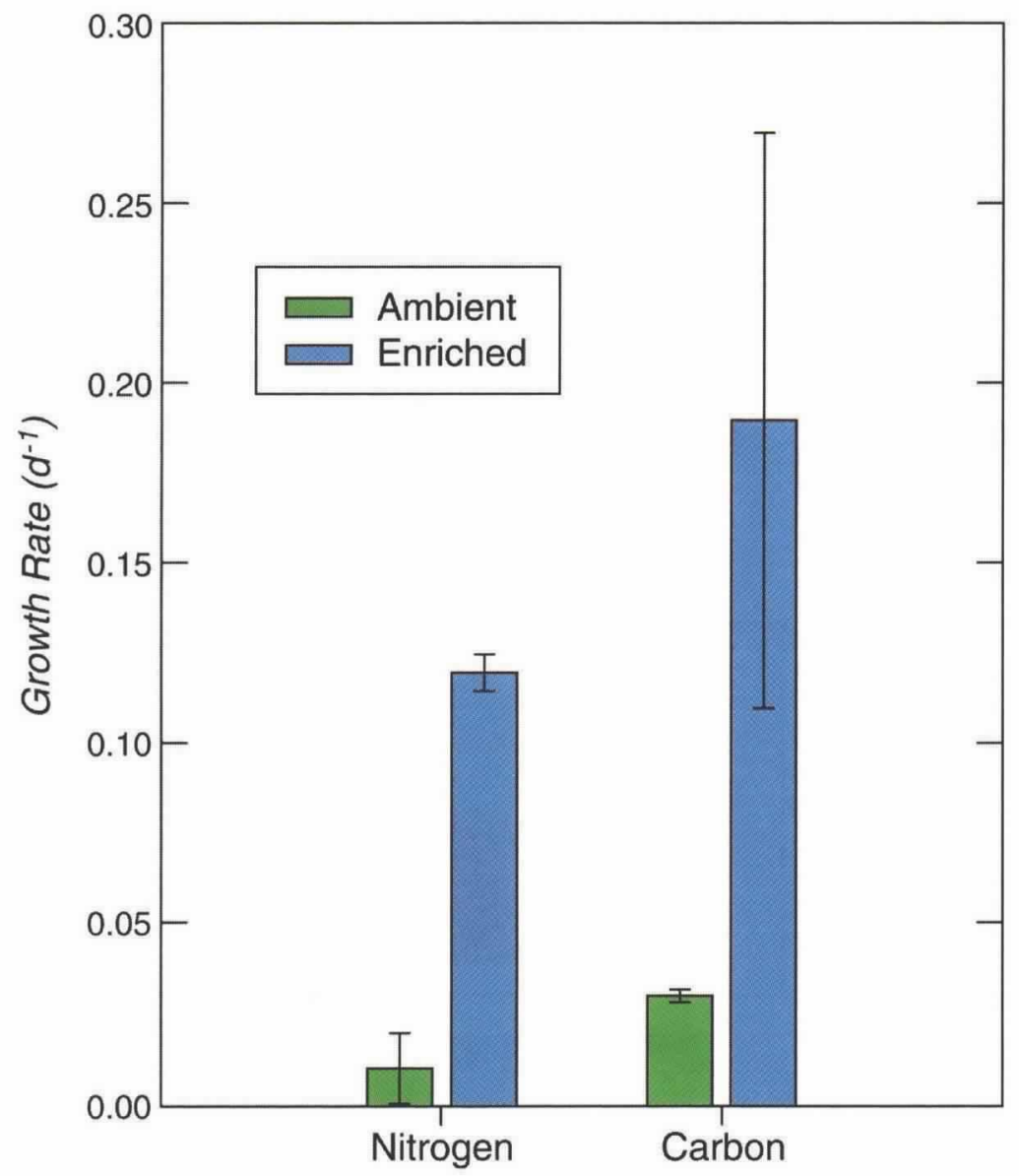

Figure 8. Growth rates in terms of nitrogen ( $\mu g N$ body mass $^{-1} d^{-1}$ ) and carbon ( $\mu g C$ body mass $^{-1} d^{-1}$ ) of Calanus finmarchicus stage $\mathrm{C} 4$ in ambient seawater and seawater enriched with phytoplankton cultures, estimated from shipboard experiments during a process cruise to the southern flank of Georges Bank on 10 April 1997. (Adapted from Campbell et al., 2001).

tion also depends on local turbulence, with high turbulence values decreasing ingestion success, resulting in a dome-shaped relationship between ingestion and turbulence. The effect of light on young larvae is to reduce prey ingestion rates at low and at high light intensities. Finally, modeled larval activity and metabolic costs are modulated by temperature.

A four-day simulation of larval cod growth in the presence of observed prey in May 1993 but with the N1-N6 stages of C. finmarchicus increased four-fold is shown in Figure 10. The growth rates peaked at $15 \%$ per day over most of the simulation in the upper $40 \mathrm{~m}$ of the water column. Peak 4-day cumulative growth rates of $10 \%$ were found at $25 \mathrm{~m}$. The spatial-temporal structure of the ingested biomass reflects the day-night cycle, the increased cloud cover on May 25-26 and the near-surface occurrence of optimum light levels at dawn/dusk.

\section{Dynamics of Copepod Target Species}

Coupled physical-biological models offer a framework for dissection of the manifold contributions to structure in observed population distributions. However, their utility is predicated on an ability to construct a simulation that is representative of the natural system. One technique for doing so (the "forward" problem) is to initialize a coupled model with a set of observations, integrate forward in time and then compare with the next set of observations. A successful outcome results in minor discrepancies between observations and predictions, and the model solutions thus can be used as a basis for diagnosis of the processes controlling the observed behavior. Unfortunately, satisfactory completion of the forward problem is not always achievable due to limitations of the models, the observations, or both. Adjoint data assimilation methods provide an alternative approach that is particularly useful in such cases (McGillicuddy et al., 1998). These techniques can be used to determine the model inputs (e.g., parameters, forcing functions, etc.) that minimize discrepancies between observations and predictions, thereby producing an optimal solution from which the underlying dynamics can be gleaned.

An example application of adjoint data assimila- 


\section{Stage-specific Mortality Patterns}

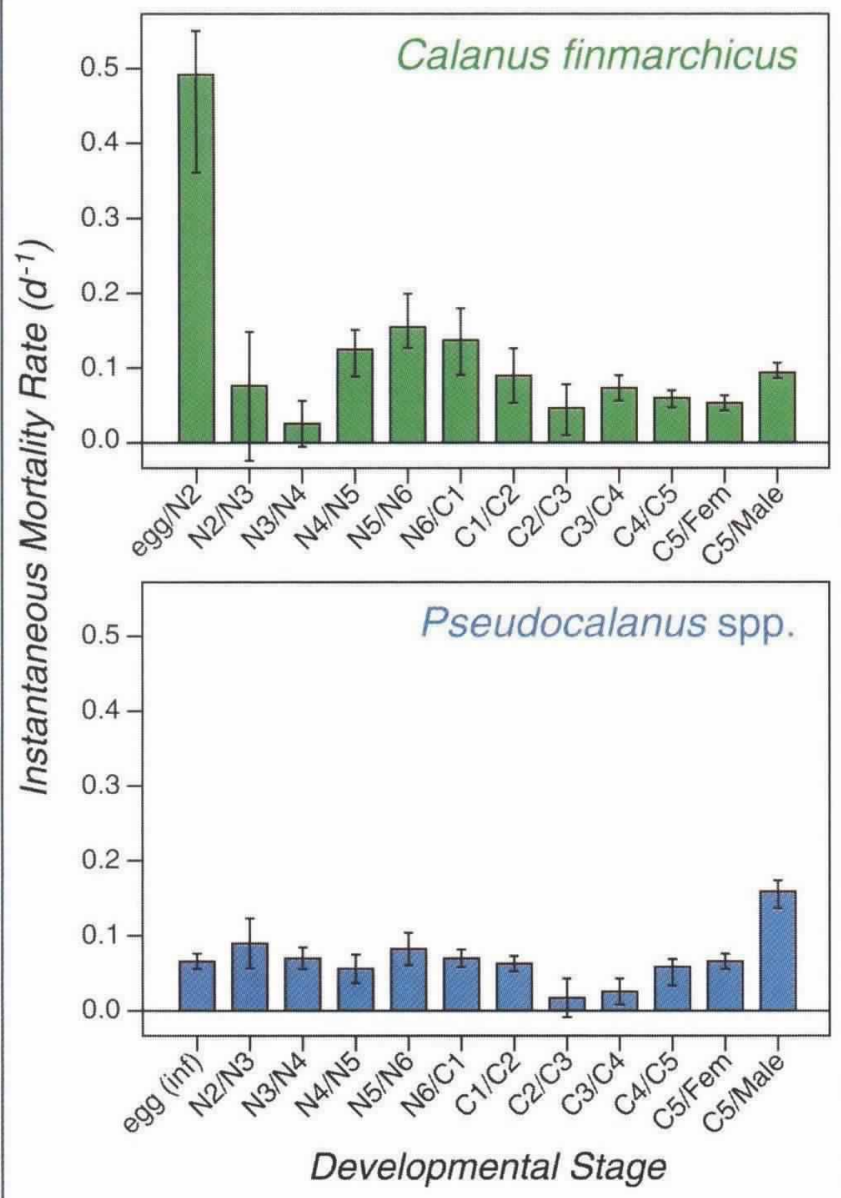

Figure 9. Stage-specific instantaneous mortality rates (medians with 95\% nonparametric confidence limits) on Georges Bank, for $A)$ Calanus finmarchicus $(N=2,555)$ and $B$ ) Pseudocalanus species ( $N=2,786)$. Mortality estimates calculated from data collected from 30 broadscale survey cruises, 1995-1999, except for egg/N2 and N2/N3 of C. finmarchicus, for which appropriate data were only available from diaphragm pump samples taken in June 1998 and January-June 1999. Since female Pseudocalanus carry their eggs until hatching, egg mortality rates in Panel $B$ are inferred to be equivalent to the C5/female rates; direct estimates were not made. (Adapted from Ohman et al., 2002).

tion using broad-scale data for adult female C. finmarchicus data is shown in Figure 11. In the February survey (panel a), four distinct maxima in abundance are present: on the northeast peak, the northeast portion of the crest just inside the $60 \mathrm{~m}$ isobath, the center of the crest, and just north of the Great South Channel. In addition, there is a broad region of low concentration south of the crest. The March survey (panel b) is characterized by a north-south band of very high abun- dance, which cuts across the center of the bank; although it is quite coherent, local maxima are clearly evident within the band. It is flanked by large areas of relatively low concentration to the east and west. The peak in abundance present just to the north of the Great South Channel in February appears to have intensified. The adjoint method permits inversion for the biological sources and sinks implied by these changes in abundance and the flow field during the intervening period (the climatological velocity and diffusivity fields from the Dartmouth circulation model are specified). Net sources occur upstream of areas in which abundance increases, whereas net sinks are required where high concentrations are advected into regions where the animals are not observed. A prime example of this occurs along the southern flank of the bank, where strong southwestward flow is present. Buildup of the peak in the vicinity of station 6 is brought about by net growth upstream (to the northeast), and net mortality downstream (to the southwest). In other areas where the mean current is weak, changes in abundance are largely controlled by local balances. Magnitudes of the biological rates created by the assimilation procedure fall within the range of observations (see McGillicuddy et al., 2001); however, the extant database is not sufficient to evaluate the spatial configuration of the source/sink distribution in the inverse solution.

A similar approach has been used to study the physical and biological controls on the springtime distributions of $P$. moultoni and P. newmani based on observations from broad-scale surveys in 1997 (McGillicuddy and Bucklin, submitted). Results of the inversions facilitate distillation of a conceptual model for how the distributions of the two species of Pseudocalanus evolve on Georges Bank (Figure 12). In April, at the beginning of the growing season, the population centers of the two species are quite distinct: $P$. moultoni is located primarily along the northwest flank of the Bank, whereas $P$. newmani predominates on the southern flank and the southern tip of Browns Bank. The joint effects of advection and net growth of both species result in distributions that overlap in June. During the growing season, the around-bank flow amalgamates the two reproducing (but not interbreeding) populations such that their initially separate centers of mass become coincident. In essence, the circulation (i.e. the combined effects of advection and diffusion) mixes the two species from their respective source regions into an overall distribution that is centered on the Bank by the end of the growing season.

\section{Synthesis}

A fourth and final phase of the U.S. GLOBEC Northwest Atlantic/Georges Bank program is now underway to enable investigators who participated in the program and other investigators to collectively bring about an integration and synthesis of the data sets in order to reach a new level of understanding about the physical and biological processes controlling 
the abundance of target species in the Georges Bank region, to provide an integrated understanding of their population dynamics and to evaluate how a varying climate may influence these populations. Phase IV is thus focused on the synthesis of the results from the program's earlier phases. The primary goal of the synthesis will be to develop conceptual and numerical coupled physical/biological models capable of addressing three primary objectives: 1) explaining the characteristic physical and biological seasonal patterns and relationships observed on the Bank; 2) reproducing the physical and biological response of the system on time scales ranging from events to interannual as observed during the program; and 3) evaluating the potential effects on the bank system of anticipated variations in climate.

During this synthesis effort, a parallel effort will be made to begin to use the knowledge, models and tech- nologies produced in this U.S. GLOBEC program to develop predictive and analytical tools for operational fisheries management. This transition from research to application will focus on three activities: 1) the adaptation of coupled bio-physical models to operational problems; 2) the development of environmental and ecosystem indices; and 3) the application of new sampling technologies to enhance monitoring programs. Examples of initial efforts in this area include the testing the Dartmouth circulation model as a tool to aid in the evaluation of Marine Protected areas in the Georges Bank region and upcoming trials of the towed video and acoustic technologies developed in this program to improve the monitoring of the zooplankton community presently done by NMFS with tradition net tows.

\section{$6 \mathrm{~mm}$ Cod, Growth \%/day (4x Cal N1-N6)}
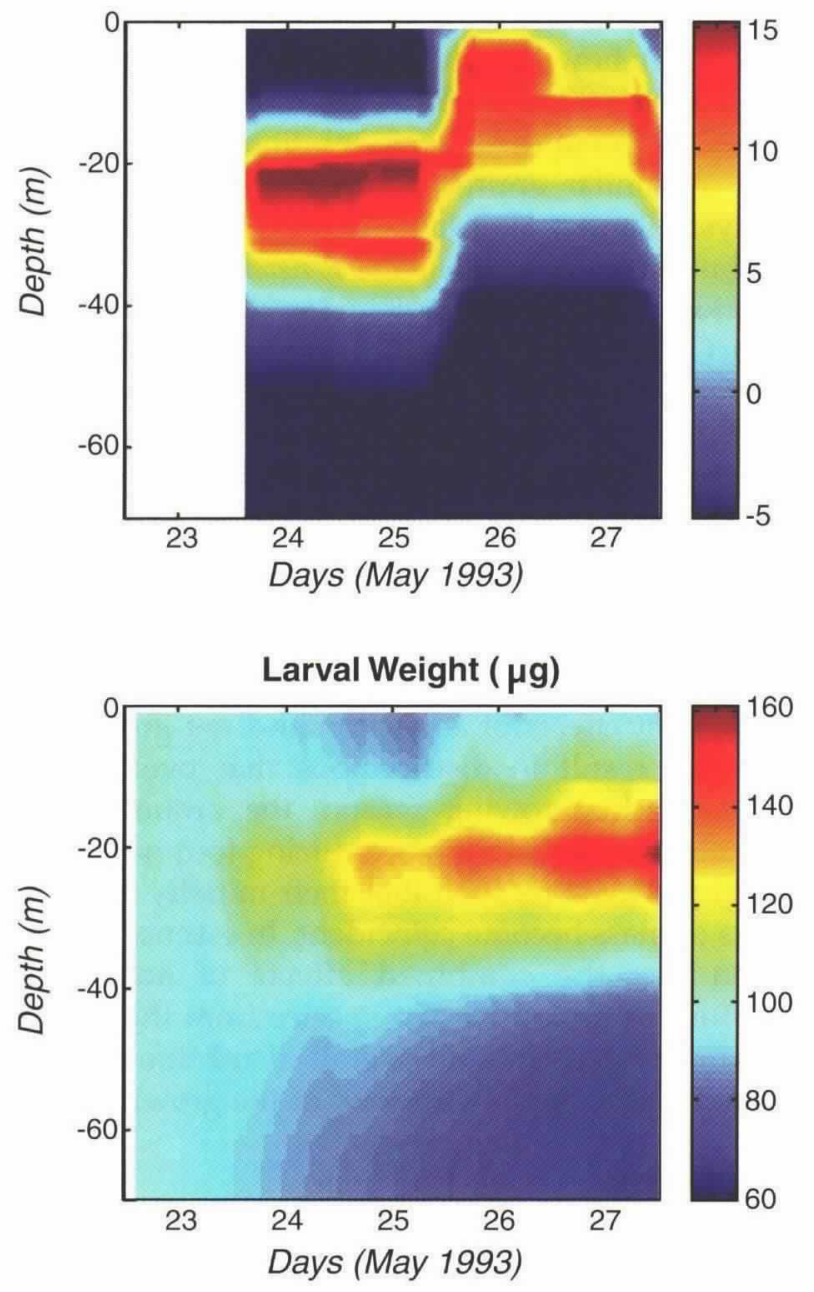

Prey Biomass Ingested $(\mu \mathrm{g})$

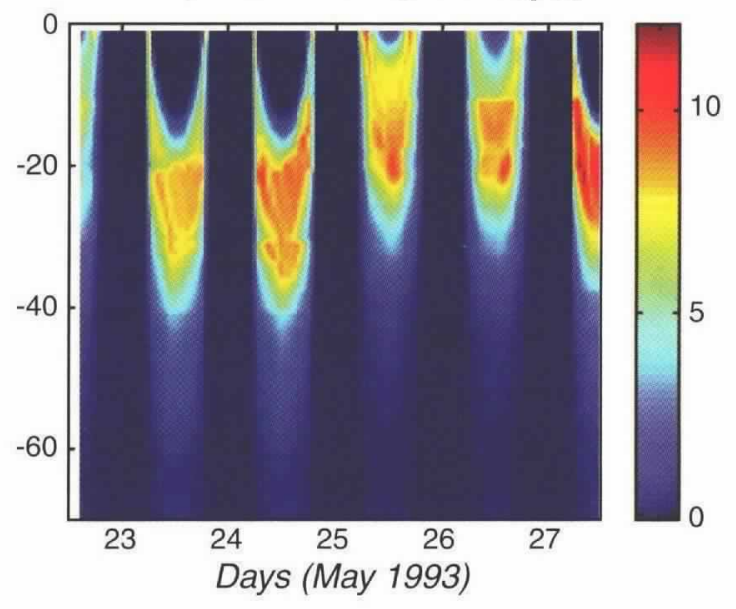

Growth Rate over 4 Days

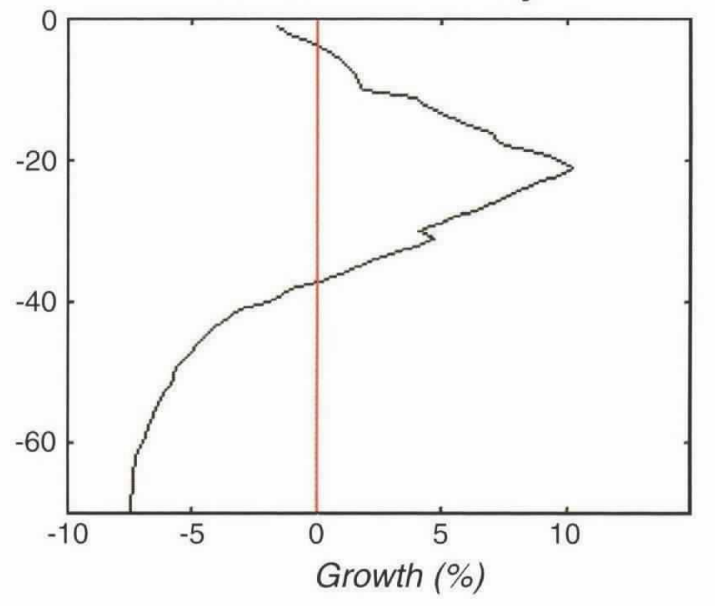

Figure 10. Daily growth rate, ingested biomass, larval weight and cumulative growth for $6 \mathrm{~mm}$ cod larvae under ambient Pseudocalanus, Oithona and Centropages concentrations. The sensitivity to an increase of Calanus nauplii is considered. 
a)

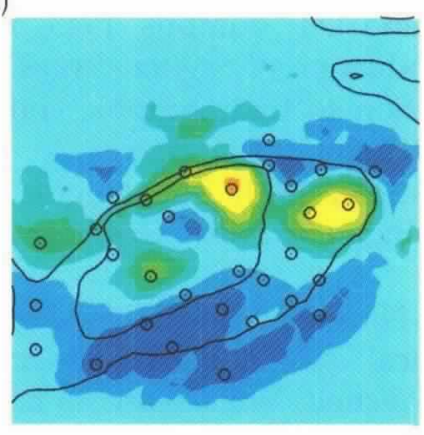

EN261 Obs (Feb 10-20) b)

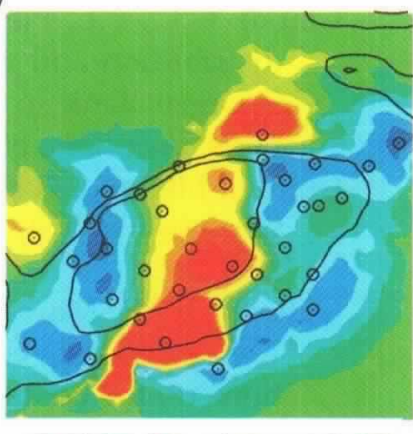

EN263 Obs (Mar 13-23) c)

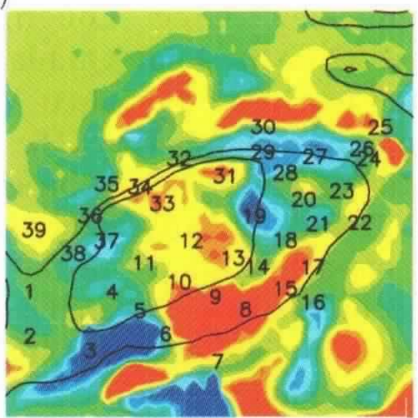

$0.8 \times 10^{-5}$

25

20

15

10

5
0

Biological Source/Sink Term

Figure 11. Objective analyses of adult female C. finmarchicus abundance (number of animals $/ \mathrm{m}^{3}$ ) observed during cruises a) EN261, and b) EN263. Panel c) shows the biological sources and sinks (number of animals $/ \mathrm{m}^{3} \mathrm{~s}$ ) inferred using the adjoint method. Note that the locations of the observations in panels a) and $\boldsymbol{b}$ ) (indicated by circles) do not exactly match each other or the station positions called for in the broad-scale sampling plan (depicted by numerals in panel c). Such discrepancies are unavoidable during normal seagoing operations. Also note that the station numbering is sequential and therefore does not correspond exactly to GLOBEC station identifiers. The $60 \mathrm{~m}$ and $100 \mathrm{~m}$ isobaths are superimposed on all panels.

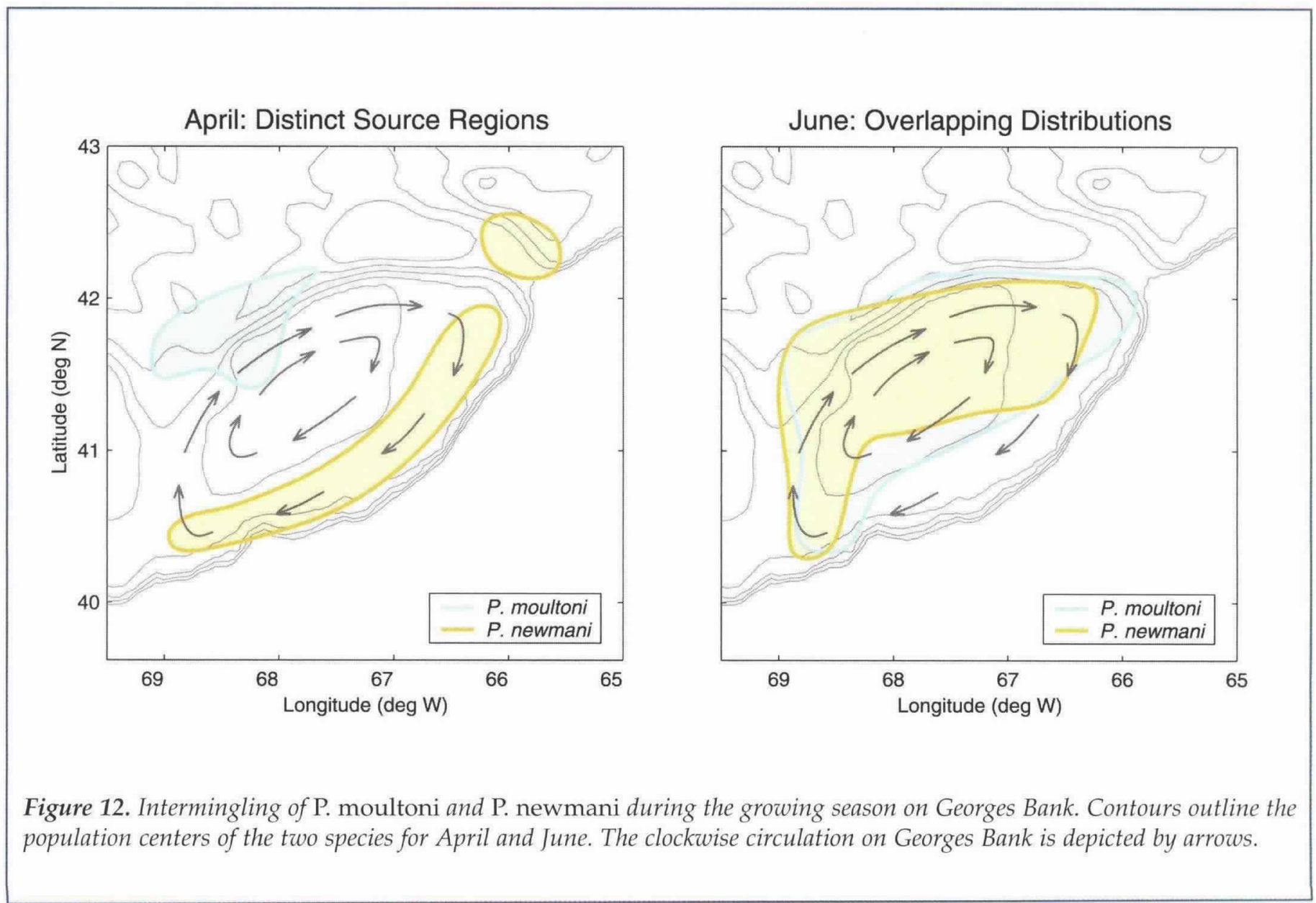




\section{Acknowledgements}

The authors want to acknowledge the contributions of Larry Buckley, Greg Lough, Dennis McGillicuddy, Mark Ohman, John Quinlan, Jeffrey Runge, David Townsend, and Francisco Werner in preparing this program review. The U.S. GLOBEC Northwest Atlantic/Georges Bank program has involved more than 70 investigators, all of whom have contributed to the research findings of the program, although only a fraction of whose research is described in detail in this review; all deserve shared credit for the success of the program. Funding for the program was provided by the National Science Foundation Ocean Sciences Division, the National Marine Fisheries Service, and the Coastal Ocean Program of the National Oceanic and Atmospheric Administration.

This is U.S. GLOBEC contribution Number 230.

\section{References}

Backus, R.H., ed., 1987: Georges Bank. MIT Press, Cambridge, Massachusetts, $593 \mathrm{pp}$.

Bigelow, H.B., 1926: Plankton of the offshore waters of the Gulf of Maine. Bull. U.S. Bur. Fish., 40, 1-509.

Bigelow, H.B., 1927: Physical oceanography of the Gulf of Maine. Bull. U.S. Bur. Fish. 40, 511-1027.

Bisagni, J.J., R.C. Beardsley, C.M. Ruhsam, J.P. Manning and W.J. Williams, 1996: Historical and recent evidence of Scotian Shelf water on southern Georges Bank. Deep-Sea Res. II, 43, 1439-1472.

Brickman, D. and J.W. Loder, 1993: Energetics of the internal tide on northern Georges Bank. J. Phlys. Oceanogr., 23, 2409-424.

Brown, R. and N.J. Munroe, 2000: Assessment of the Georges Bank Haddock, 1931-1999. National Marine Fisheries Service, Northeast Fish. Sci. Cent. Ref. Doc. 00-12.

Buckley, L.J. and R.G. Lough, 1987: Recent growth, biochemical composition, and prey field of larval haddock (Melanogrammuls aeglefinuts) and Atlantic cod (Gadus morhua) on Georges Bank. Can. I. Fish. Aquat. Sci. 44, 14-25.

Buckley, L.J., E.M. Caldarone and R.G. Lough, 2002: Optimum temperature and food limited growth of marine fish larvae: Implications to climate change. Fish. Oceanogrr., submitted.

Campbell, R.G., J.A. Runge and E.G. Durbin, 2001: Evidence for food limitation of Calanus finmarchicus production rates on the southern flank of Georges Bank during April, 1997. Decp-Sea Res. II, 48, 531-550.

Campbell, R.G., M.W. Wagner, G.J. Teegarden, C.A. Boudreau and E.G. Durbin, 2001: Growth and development rates of the copepod Calanus finmarchicus reared in the laboratory. Mar. Ecol. Prog. Ser., 221, 161-183.

Chen, C., and R.C. Beardsley, 1998: Tidal mixing and cross-frontal particle exchange over a finite-amplitude asymmetric bank: A model study with appli- cation to Georges Bank. J. Mar. Res., 56(6), 1163-1201.

Clarke, G.L., E.L. Pierce and D.F. Bumpus, 1943: The distribution and reproduction of Sagitta elegans on Georges Bank in relation to hydrographic conditions. Biol. Bull., 85, 201-226.

Colton, J.B. and R.F. Temple, 1961: The enigma of Georges Bank spawning. Limn. and Oceanogr., 6, 280-291.

Colton, J.B., R. Marak, S. Nickerson and R. Stoddard, 1968: Physical, chemical and biological observations on the continental shelf, Nova Scotia to Long Island, 1944-1966. U.S. Fish Wildl. Serv. Data Rept., No. 23, 189 pp.

Corkett, C.J. and I.A. McLaren, 1978: The biology of Pseudocalanus. Adv. Mar. Biol., 15, 1-231.

Davis, C.S., 1984: Interaction of a copepod population with the mean circulation on Georges Bank. J. Mar. Res., 42, $573-590$.

Drinkwater, K.F., D.G. Mountain and A. Herman, 2002: Variability in the slope water properties off eastern North America and their effects on the adjacent shelves. J. Gcophys. Res., submitted.

Dugdale, R.C. and J.J. Goering, 1967: Uptake of new and regenerated forms of nitrogen in primary productivity. Limn. Oceanogr., 12, 196-206.

Durbin, E., J.A. Runge, R. Campbell, P. Garrahan, M. Casas and S. Plourde, 1997: Late fall-early winter recruitment of Calanus finmarchicus on Georges Bank. Mar. Ecol. Progr. Ser., 151, 103-114.

Eppley, R.W. and B.J. Peterson, 1979: Particulate organic matter flux and planktonic new production in the deep ocean. Nature, 282, 677-680.

Franks, P.J.S. and C. Chen, 2001: A 3-D prognostic model study of the ecosystem over Georges Bank and adjacent coastal regions. Part II: Coupled biological and physical model. Deep Sea Res., 48, $457-482$.

GLOBEC, 1992: Northwest Atlantic Implementation Plan. U.S. Global Ocean Ecosystems Dynamics Report $6,69 \mathrm{pp}$.

Hannah, C.G., C.E. Naimie, J.W. Loder and F.E. Werner, 1998: Upper-ocean transport mechanisms from the Gulf of Maine to Georges Bank, with implications for Calanus supply. Con. Shelf Res., 17, 1887-1911.

Herman, Y., 1979: Plankton distribution in the past. In: Zoogeography and Diversity of Plankton. S. Van Der Spoel and A.S.C. Pierrot-Bults, eds., Halsted Press, New York, 29-49.

Houghton, R.W. and C. Ho, 2001: Diapycnal flow through the Georges Bank tidal front: A dye tracer study. Geoplyys. Res. Letts., 28, 33-36.

Laurence, G.C. and C.A. Rogers, 1976: Effects of temperature and salinity on comparative embryo development and mortality of Atlantic cod (Gadus morlutu L.) and Haddock (Melanogrammus aeglefinus L.). J. Cons. Int. Explor. Mer, 36, 220-228.

Lewis, C.V.W., C. Chen and C.S. Davis, 2001: Effect of 
winter wind variability on plankton transport over Georges Bank. Deep-Sea Res. II, 48,137-158.

Lough, R.G., 1984: Larval fish trophodynamic studies on Georges Bank: Sampling strategy and initial results. In: The Propagation of Cod Gadus Morhua L., E. Hahl, D.S. Danielssen, E. Moksness and P. Solemdal, eds., Flodevigen Rapportser, 1, 395-434.

McGillicuddy, D.J., D.R. Lynch, A.M. Moore, W.C. Gentleman, C.S. Davis and C.J. Meise, 1998: An Adjoint Data Assimilation Approach to diagnosis of physical and biological controls on Pseudocalanus spp. in the Gulf of Maine-Georges Bank Region. Fish. Oceanogr., 7, 205-218.

McGillicuddy, D.J., D.R. Lynch, P. Wiebe, J. Runge, E.G. Durbin, W.C. Gentleman and C.S. Davis, 2001: Evaluating the synopticity of the U.S. Globec Georges Bank Broad-scale sampling pattern with Observational System Simulation Experiments. Deep-Sea Res. II, 48, 483-499.

McGillicuddy, D.J. and A.C. Bucklin, 2002: Intermingling of two Pseudocalanus species on Georges Bank. J. Mar. Res., submitted.

MERCINA (A.J. Pershing, C.H. Greene, C. Hannah, D. Sameoto, E. Head, D.G. Mountain, J.W. Jossi, M.C. Benfield, P.C. Reid, and T.G. Durbin), 2001: Oceanographic responses to climate in the Northwest Atlantic. Oceanography, 14(3), 76-82.

Mountain, D.G., J. Kane and J. Green, 2000: Environmental forcing of iariability in zooplankton abundance and cod recruitment on Georges Bank. ICES CM 2000/M, 15 pp.

Mountain, D.G., 2002: Variability in the properties of shelf water in the Middle Atlantic Bight. J. Geophys. Res., in press.

Naimie, C.E. 1996: Georges Bank residual circulation during weak and strong stratification periodsprognostic numerical model results. J. Geophys. Res., 101, 6469-6486.

O'Brien, L. and N.J. Munroe, 2000: Assessment of the Georges Bank Atlantic cod stock for 2000. National Marine Fisheries Service, Northeast Fish. Sci. Cent. Ref. Doc. 00-17.

Ohman, M.D., J.A. Runge, E.G. Durbin, D.B. Field and B. Niehoff, 2002: On birth and death in the sea. Hydrobiol., in press.

O'Reilly, J.E., C. Evans-Zetlin, and D.A. Busch, 1987: Primary Production. In: Georges Bank. R.H. Backus, ed., The MIT Press, Cambridge, MA, 220-233.

Page, F.H., M. Sinclair, C.E. Naimie, J.W. Loder, R.J. Losier, P.L. Berrien, R.G. Lough, 1999: Cod and haddock spawning on Georges Bank in relation to water residence times. Fish. Oceanogr., 8, 212-226.

Pastuszak, M., W.R. Wright and D. Patanjo, 1982: One year of nutrient distribution in the Georges Bank region in relation to hydrography. J. Mar. Res., 14, $525-542$.

Polacheck, T., D. Mountain, D. McMillan, W. Smith and P. Berrien, 1992: Recruitment of the 1987 year class of Georges Bank haddock (Melanogrammus aeglefi$n u s)$ : the influence of unusual larval transport. Can. J. Fish. Aquat. Sci., 49, 484-496.

Riley, G.A., 1941: Plankton studies. IV Georges Bank. Bull. Bingham Oceanogr. Coll., 7, 1-73.

Runge, J.A., J. Quinlan, E. Durbin, C. Werner, G. Lough, L. Buckley, E. Caldarone, L. Incze, J. Manning, D. Mountain, B. Niehoff and S. Plourde, 2000: The effect of spatial and temporal viariation in zooplankton concentrations on larval cod growth and survival on Georges Bank: A sensitivity analysis based on modeling and obseriations. ICES. C.M. 2000/M:24

Smith, P.C., R.W. Houghton, R.G. Fairbanks and D.G. Mountain, 2001: Interannual variability of boundary fluxes and water mass properties in the Gulf of Maine and on Georges Bank: 1993-1997. Deep-Sea Res. II, 48, 37-70.

Townsend, D.W., 1998: Sources and cycling of nitrogen in the Gulf of Maine. J. Mar. Sys., 16, 283-295.

Townsend, D.W. and N.R. Pettigrew, 1997: Nitrogen limitation of secondary production on Georges Bank. J. Plankton Res., 19, 221-235.

Townsend, D.W. and A.C. Thomas, 2001: Winter-spring transition of phytoplankton chlorophyll and inorganic nutrients on Georges Bank. Deep-Sea Res. II, $48,199-214$.

Townsend, D.W. and M. Thomas, 2002: Springtime nutrient and phytoplankton dynamics on Georges Bank. Mar. Ecol. Progr. Ser., 228, 57-74.

Walford, L.A., 1938: Effects of currents on the distribution and survival of eggs and larvae of haddock (Melanogrammus aeglefinus) on Georges Bank. Bull. U.S. Bur. Fish., 29, 1-73.

Werner F.E., F.H. Page, D.R. Lynch, J.W. Loder, R.G. Lough, R.I. Perry, D.A. Greenberg and M.M. Sinclair, 1993: Influence of mean 3-D advection and simple behavior on the distribution of cod and haddock early life stages on Georges Bank. Fish. Oceanogr., 2, 43-64.

Werner F.E., R.I. Perry, R.G. Lough and C.E. Naimie, 1996: Trophodynamic and advective influences on Georges Bank larval cod and haddock. Deep Sea Res. II, 43, 1793-1822.

Werner F.E., B.R. MacKenzie, R.I. Perry, R.G. Lough, C.E. Naimie, B.O. Blanton and J.A. Quinlan, 2001: Larval trophodynamics, turbulence, and drift on Georges Bank: A sensitivity analysis of cod and haddock. Sci. Mar., 65(suppl. 1), 99-115. 